\title{
GCU
}

Glasgow Caledonian

University

University for the Common Good

\section{Who cares? The social care sector and the future of youth employment}

Montgomery, Thomas; Mazzei, Micaela; Baglioni, Simone; Sinclair, Stephen

Published in:

Policy and Politics

DOI:

$10.1332 / 030557316 \times 14778312165186$

Publication date:

2017

Document Version

Author accepted manuscript

Link to publication in ResearchOnline

Citation for published version (Harvard):

Montgomery, T, Mazzei, M, Baglioni, S \& Sinclair, S 2017, 'Who cares? The social care sector and the future of youth employment', Policy and Politics, vol. 45, no. 3, pp. 413-429.

https://doi.org/10.1332/030557316X14778312165186

\section{General rights}

Copyright and moral rights for the publications made accessible in the public portal are retained by the authors and/or other copyright owners and it is a condition of accessing publications that users recognise and abide by the legal requirements associated with these rights.

Take down policy

If you believe that this document breaches copyright please view our takedown policy at https://edshare.gcu.ac.uk/id/eprint/5179 for details of how to contact us. 


\title{
Who Cares? The social care sector and the future of youth employment
}

\author{
Montgomery, T., Mazzei, M., Baglioni, S., Sinclair, S.
}

\section{Introduction: matching the recruitment needs of the social care sector and the employment needs of young people}

With an estimated 21.789 million European Union (EU) residents unemployed in January $2016^{1}$, of which 4.434 million were young people (under 25), it is no surprise that one of the key targets in the Europe 2020 strategy is to have $75 \%$ of the active population (20-64 year-olds) in employment by the end of the decade. Numerous initiatives have been promoted to support job creation, such as increased lending to small businesses, reduced employment taxes, encouraging entrepreneurship whether social or traditional - and stimulating the creation of new firms among adults and young people alike ${ }^{2}$ (see also Bridge, 2010). To achieve this aim, the European Commission has also increased the promotion and support of microfinance for young entrepreneurs ${ }^{3}$. Various programmes are designed to improve the employability of young people via education and in-work training (apprenticeships) that match employers' needs, mobilising the European Social Fund and the Lifelong Learning Programme to fund such initiatives. Analysis of emerging trends at the sectoral level to anticipate future skills needs has led policymakers to focus upon the social care sector and harnessing its potential is one of the measures to support job creation proposed in the Employment Package launched by the European Commission in April $2012^{4}$.

Policymakers across Europe have therefore begun to consider the potential of the social care sector and to promote it as a career option for young people. In the UK, for example, Skills for Care (2014) has estimated that the growing demand will require 800,000 additional jobs being created in the social care sector by 2025 . The paradox is however, that despite growing demand, spending on some parts of the social care sector is contracting with Age UK (2014) warning against the negative impact real-term spending cuts are having upon the sector. Therefore, one wonders if the discrepancy between the policy rhetoric and the actual investment required in the sector could expose young people to an even greater risk of precarious employment. Consequently this paper argues that job creation strategies centred around sectors with high levels of employment insecurity such as social care, risk reinforcing the precarity which characterises the contemporary labour market, evidenced by a substantial literature (della Porta et al, 2015; Shildrick et al, 2012; MacDonald, 2011; Standing, 2011; Furlong and Kelly, 2005; Furlong and Cartmel, 2004), and pave the way for the further precariatization of employment, and in particular youth employment.

\footnotetext{
${ }^{1}$ http://ec.europa.eu/eurostat/statisticsexplained/index.php/Unemployment statistics\#Recent developments in unemployment at a European and Member State level

${ }^{2}$ http://ec.europa.eu/social/main.jsp?catld=1039

3 http://ec.europa.eu/social/main.jsp?catld=950\&langld=en and http://ec.europa.eu/social/main.jsp?catld=822\&langld=en

${ }^{4}$ http://ec.europa.eu/social/main.jsp?catld $=1039$
} 
To address such concerns, much of the policy focus in matching the needs of the social care sector labour market with those of young people involves improving the image of the sector to become more attractive to younger recruits, and improving the skills of young people to match employers' requirements. This approach - designed to ensure that young people are 'job ready'- risks mistakenly prioritising supply (skills and employability) over demand side issues, such as the quality of employment, the social care market place and the suitability of young people as employees in specific subsectors of social care. There is also the question of how the social care sector can improve its image in a climate of budgetary constraints? How can it become more attractive to potential applicants if it is struggling to fund a living wage, provide training opportunities or career progression prospects to its workforce? In practice the answer seems to rest upon the need of employees to accept 'flexibility' and 'precarity' both in working conditions and career progression.

Our investigation of the views of young people and social care providers through the case study of Scotland reveals that a more integrated and balanced approach to harnessing the potential of the social care sector is required to stimulate sustainable youth employment and that such an approach should be considered by policymakers across Europe. While matching sector needs with young people's needs may be a worthy policy objective, its current implementation should be reconsidered, as it risks privileging supply side over demand side factors with little consideration of what employers really require and the difficulties they face in delivering services. Risk is shifted onto individuals - who need to upskill to match market needs - or indeed firms providing care services needing to promote their sector, provide training and sustain service delivery. However, in a context of poor career prospects, constrained private and public funding for social care and the increased marketization of welfare/care, can the sector provide a viable solution to youth unemployment? And what type of job opportunities, in terms of employment quality, does it actually provide for young people?

The first section of this paper discusses the policy and labour market context, which have combined to increase the responsibilities of both individuals and social care providers and have therefore contributed towards creating the conditions for precariousness to develop further. Following a brief outline of the research methods and data sources, the results of this empirical investigation are then presented, focusing upon employers' and young people's perspectives of employment in social care. The paper concludes with some reflections regarding a more balanced and sustainable policy approach.

\section{Labour Market Policy Context}

Scotland presents a particularly interesting case to investigate as data from the Scottish Social Services Council (SSSC, 2015) indicate that between 2013 and 2014, staff numbers in the social care sector rose by approximately 5.3\%, reversing a recent trend in falling headcount and making current workforce numbers the highest since records began. From the 18 sub-sectors $^{5}$ of social care, 13

\footnotetext{
${ }^{5}$ These are: Adoption services; Adult day care; Adult placement services; Care homes for adults; Central and strategic staff; Child care agencies; Childminding; Day care of children; Fieldwork service (adults); Fieldwork service (children); Fieldwork service (generic); Fieldwork service (offenders); Fostering services; Housing support/care at home; Nurse agencies; Offender accommodation services; Residential child care; School care accommodation.
} 
reported a rise in workforce numbers, the largest being that of housing support/care at home. These increases in the number of care workers are taking place within a period of reorganisation in Scotland towards health and social care integration, a process which has repeatedly encountered difficulties in other parts of the UK (Hudson and Henwood, 2002; Ellis, 2015). Moreover, a context of tight public finances and competition amongst providers has driven down costs, causing low wages and threatening employment security.

Scotland shares longstanding youth employment issues with many European countries and like those countries continues to search for policies to address youth unemployment. The number of young (i.e. 16-24 years old) jobless in Scotland rose from 49,000 in early 2008 to a peak of 113,000 in the summer of 2011 (Scottish Government, 2012, 3). Between April 2011 and March 2012 the number of young unemployed people was 88,000 , although this decreased to 58,000 in the year October 2014 to September $2015^{6}$ (Scottish Government, 2016). The Scottish Government has formulated and implemented a dedicated 'youth employment strategy' to tackle this problem and more recently have committed to 'reducing 2014 levels of youth unemployment by 40 per cent by 2021' (Scottish Government, 2014, iii). Despite these measures and strategic objectives, critics point out that the Scottish Government's decision to focus so heavily upon unemployment neglects the multiple problems arising from precarity (see below) and underemployment (where workers would work more hours if it was possible) which characterise contemporary labour markets for young people in Scotland and many other European countries. Figures from the Office for National Statistics (2014) demonstrate that underemployment is skewed heavily towards younger workers with one in five 16-24 year olds in the UK underemployed, more than double the figures for any other age group.

The Scottish Parliament's Economy, Energy and Tourism Committee have expressed concerns about the increasing levels of insecure employment. The report concluded that 'the Committee is particularly concerned by the higher levels of underemployment experienced by young people. Not only does underemployment inhibit young people's capacity to be independent, but it has a longterm effect on employment prospects' (Scottish Parliament Economy, Energy and Tourism Committee, 2013, 17). Nevertheless despite such concerns, Scotland's youth employment strategy does not yet seem to have fully absorbed the impact of these factors on the lives of young workers.

The current UK constitutional settlement devolves responsibility for skills and employability to the Scottish Parliament, but primary responsibility for employment and welfare policy remains reserved to Westminster. Therefore a thorough analysis of the measures implemented in Scotland to address youth employment issues cannot be detached from the UK policy context. This has created a deindustrialised labour market environment, with weakened trade unionism, deregulation and flexibility (Jessop, 2003). These policies have been pursued in a globalised post-Fordist context (Jessop, 1994; 2003) in which sectors that employed large numbers of workers (e.g. manufacturing) have drastically diminished in labour-absorption capacity, while demands in others have increased (e.g. social work or health) although not enough to compensate for the jobs lost. Jessop $(1994 ; 2003)$

\footnotetext{
${ }^{6}$ These data refer to the Annual Population Survey (APS), whereas another source, the Labour Force Survey (LFS) estimates that in October to December 2015 youth unemployment rose in Scotland by 4,000. We use the APS as a primary reference here because it is considered a more reliable source for employment/unemployment data due to its larger sample size and the fact that it is not affected by seasonality.
} 
argues that the discourse of employment in the UK has shifted from a focus on demand side deficiencies to a debate on the supposed deficiencies of the individual worker, which arguably can be extended to some firms which are required to create jobs, provide training opportunities, and (in the specific case of the social care sector) enhance its reputation as a 'good employer'. These expectations give little consideration to both the difficulties currently faced by employers in some sectors due to public budget cuts, or the changed nature of youth employment which due to its insecure and volatile nature (or 'precarity') may have negative implications for workers' health and well-being (Benavides and Benach, 1999; Benach et al, 2002).

The effects of deregulation and flexible employment policies have accelerated, with many young people in Scotland employed through non-standard forms of employment such as zero hour contracts and experiencing lower wages than previous generations (Scottish Affairs Committee, 2014). These young people have found themselves enmeshed in 'a process by which less advantaged positions in the labour market are made even more precarious through various policy and regulatory processes' (Furlong and Kelly, 2005, 223). Consequently, young people who do manage to find employment are often exposed to the pernicious consequences of fragile labour markets (Furlong and Cartmel, 2004; MacDonald and Marsh, 2005; MacDonald et al, 2005; MacDonald, 2011; Shildrick et al, 2012).

These labour market conditions and employment experiences have led some scholars to suggest that a new 'precariat' class has emerged (Standing, 2011; della Porta et al, 2015). These are workers whose insecurity limits their capacity to build positive social relationships through employment and leads workers to view colleagues as competitors rather than allies. In these insecure markets young people are under increasing pressure to personally manage and market their individual 'employability' (Peck and Theodore, 2000; Cremin, 2010). Discourses which individualise responsibility have been explored elsewhere (see Foucault, 2010; Rose, 2000); however whether or not insecurity and individualisation are reflected in or reinforced by contemporary policies which seek to absorb young people in sectors such as social care deserves further analysis and the objective of this paper is to contribute towards that analysis by focusing on one context. When discussing care policy development in the Scottish case we pursue a twofold aim: on the one hand, we provide new evidence about how care providers and potential young employees experience and perceive what is considered a strategic sector for job creation (and a strategic sector well beyond Scotland), and therefore we contribute towards the assessment of whether the policy rhetoric in support of the sector is mirrored by the experience of those working in it, or who could work in the sector. On the other hand, by questioning the capacity of the care sector to produce stable and good quality jobs in the current economic climate, we contribute towards deepening the theoretical discussion about the changing patterns of youth employment in Europe, and in particular, patterns of precariatization.

\section{Social Care Policy Context}

The landscape of social care in Scotland is currently experiencing a period of transition through the flagship policy of the Scottish Government to integrate the provision of health and social care, detailed in the Public Bodies (Joint Working) (Scotland) Act 2014. The purpose of such integration is to meet the challenges presented by an ageing population by focusing on providing services in a 
community based setting. The legislative framework for these changes outlines the options for the integration of services to be considered by health boards and local authorities and requires them to submit an 'integration scheme' for approval by the Scottish Government. These integration schemes provide a blueprint of how key matters are addressed including financial management, local arrangements for operational delivery and workforce development. There have however been some early indications that the implementation of the integration schemes will bring challenges for policymakers. A report published in December 2015 by Audit Scotland - the agency working on behalf of Scotland's public spending watchdogs, the Accounts Commission and the Auditor General has raised concerns regarding the complex governance and budgetary agreements for the new arrangements but has also underlined the importance of making careers in caring more attractive, placing a focus upon key workforce development issues, stressing that, 'at present, few IAs (Integration Authorities) have developed a long-term workforce strategy. Developing a suitably skilled workforce is crucial to the success of integrated health and social care services' (Audit Scotland, 2015, 33). Therefore the issues surrounding careers in care not only impact upon the prospects for young people entering the labour market, they also underpin the potential success and sustainability of the future provision of integrated health and social care services.

\section{Harnessing the potential of the social care sector for young people}

The Scottish Social Services Council (SSSC) is the regulatory body which registers and regulates key groups of social service workers, promotes and regulates education and training, raises the standards of practice by social service workers and has been involved in promoting the social care sector as a career choice among young people. One of their aims has been to improve the image of the social care sector by portraying it as a career choice rather than merely a job for those with no alternative. Social care jobs are often demanding and poorly paid, and many people opt for such positions when other opportunities are unavailable, and they tend to leave these jobs when other opportunities arise (Scottish Care, 2015). The fact that working in the social care sector can mean insecurity and 'flexible' career progression entails the risk that current policy initiatives will normalise or exacerbate precarious work and contribute towards entrenching rather than alleviating contemporary youth employment problems.

The youth employment agenda in Scotland has become increasingly focused upon young people in school. The Scottish Government's education programme, Curriculum for Excellence, has emphasised the participation of employers in secondary education in order to focus learning upon areas that will enhance the employability of young people. The Scottish Government has also placed considerable emphasis on 'Modern Apprenticeships' which are administered by Skills Development Scotland. There are seven frameworks of apprenticeships in social care across the country designed to attract young people to the sector. Another measure to improve the 'attractiveness' of the social care sector among school leavers is the Care Ambassador scheme which forms part of the UK-wide 'Building a World-class Workforce' programme. However, there is no consistency across the UK in how this programme is implemented, and divergences are evident reflecting different geographic, demographic and socio-economic characteristics. The programme includes working with schools to invite Ambassadors to raise awareness of the career choices and prospects available in the social care sector. Young people are encouraged to view such career pathways as opportunities 'to move across the ladder horizontally', meaning they can gain experience working for different 
organisations, but perhaps thereby ingraining the concepts of flexibility and insecurity (Furlong and Cartmel, 2004; Furlong and Kelly, 2005; Standing, 2011; Shildrick et al, 2012).

\section{Methodology}

The research underpinning this paper stems largely from a European project ${ }^{7}$ which involved experts from a range of countries mapping trends in youth (un)employment, policies and programmes to raise awareness among young people and employers (i.e. providers) of opportunities in the social care sector. The project sought to understand issues affecting the target groups by balancing the analysis of the supply of and demand for labour. It involved consulting social care providers and umbrella organisations representing the social care sector in central Scotland as well as interviews and focus groups with young people aged between 16-24 who were about to complete a period of higher education.

It soon became apparent that there were some difficulties recruiting participants from both our target groups: social care providers and young people about to enter the labour market. Social care providers were reticent about exploring the potential of employing young people, a theme conspicuous by its absence in most of the early communication with this group. This was resolved by involving representative 'umbrella' bodies of both private and third sector providers. From an initial list of eleven providers and member organisations, we conducted face-to-face in-depth interviews, based on a semi-structured questionnaire, with five representatives from four organisations. Interviews lasted on average for one hour. Interviewers' notes were analysed by three researchers, and interpretations cross-checked. Similarly, although we set out to recruit young participants using a variety of methods across different institutions and educational courses, young people were reluctant to participate when they became aware that the discussion focused upon careers in the social care sector; some of the reasons for this are discussed in the next section. Therefore different recruitment strategies had to be adopted. As the young people were reluctant to discuss social care, the researchers had to engage them on this topic as part of a broader discussion about employability. The first attempt to hold a focus group resulted in only one participant turning up. We therefore conducted an in-depth interview with this person. Subsequently we held a focus group with four young participants. Notes taken during both events were subsequently analysed by the research team.

Another interesting finding concerned the extent of our young participants' existing employment, despite the fact that they were in full-time education and most had entered further or higher education directly from school. For example, each of the four focus group participants indicated that they had at least two years of paid employment or voluntary experience, with some indicating more than five years' experience. Similarly, in the focus group and during the in-depth interview, young people tended to emphasise their work experience. Such labour market experience suggests that these young people can develop early perceptions of the employment opportunities and risks that they may encounter when leaving education.

\footnotetext{
${ }^{7}$ Skills and Labour Market to Raise Youth Employment.
} 


\section{Employers and young people's perspectives of social care: emerging themes and challenges}

The views articulated by social care providers and young people reflect several concerns about wider labour and provision markets which Scotland shares with several European countries. Social care providers indicated that they face enormous challenges in recruiting and retaining staff, mainly because of decreasing resources. When considering the social care sector, the young people we spoke to expressed concerns about the potential low pay and poor conditions in relation to their perception of the intensity of the work involved. Moreover, there was a consensus among these young people that working in the social care sector with potentially vulnerable clients required certain aptitudes which could not be taught. It became clear during the discussion that these views were firmly held by the young people and had been formed in part by their perceptions of the everyday lives of elderly people in their own families and communities. Overall, our research has revealed that a combination of factors concerning both the supply of labour and the demand for it pose considerable challenges in attracting young people to a career in the social care sector.

\section{Resource scarcity in the social care sector}

Wider economic and financial contexts have had an impact on local authority budgets and social care funding. Care services have suffered from public service cuts, which have triggered a reduction in council care provision, an increase in the charges councils make for care services and a reduction in the number of older people eligible to receive support from councils (Age UK, 2014), as the following quote indicates:

"There is really no growth in provision in the voluntary social care sector. The market is standing still... There is potential in the social care sector, but in a market place that is not growing. This is a consideration that is valid both for private and voluntary sector providers. The irony is that despite the ageing population, growing needs for social care and the potential that the personalisation agenda can offer, the sector is struggling. Local authority spend in social care is reducing and providers are not finding profitability in the services they provide. There is a definite gap in the labour market" (Provider 1).

This resonates with findings from Age UK research (2014) revealing a $10 \%$ decrease in public funding for older people's social care between 2010/11 - 2013/14. In Scotland, although the Scottish Government has committed to investing in better social care outcomes the budgetary agreements involving health and social care integration remain uncertain. What is certain is that reductions in funding can have an impact on the social care workforce, both in terms of recruitment and retention as well as investment in development. For example, workers in the care sector are typically lower paid (minimum wage) than in other sectors (Low Pay Commission, 2010). The implications of this were noted by some of those we interviewed:

"A corollary to the discussion is that the cost of private care homes is around $f 500$ per week per person. This equals to $f 3$ per hour per day. The local authorities have been trying to keep the costs down but the local authority provision is around 1800 per week. In order to keep the price competitive and in absence of any other type of support or recognition of the effort, staff are paid minimum wage or in some cases (depending on the local authority) a living wage" (Provider 2). 
The challenge of delivering services while keeping costs competitive has led to a neglect of workforce development. Some interviewees suggested that offering staff career development opportunities is a challenge for underfunded organisations, particularly smaller ventures. Such resource scarcity creates problems in recruiting and retaining staff:

"Our members find that in some geographical areas recruitment is more problematic than others. For example, in rural areas it is more difficult to recruit and/or retain staff. Whilst in many cases a care home may be the main employer, it is still competing with other industries. People working in ASDA for example may get paid the same as those working in social care, but they get a 15\% off their food bill" (Provider 2).

Indeed recent research has highlighted the poor pay and conditions currently experienced by many social care workers in Scotland and the UK:

"The Low Pay Commission and others have repeatedly flagged social care as a sector of concern in terms of compliance with the National Minimum Wage (NMW). The workforce displays many of the characteristics we associate with low pay: disproportionately part-time (38\%) and female (83\%), with growing numbers of migrant workers, low levels of formal qualifications, and a weak collective voice" (Gardiner, 2015, 2).

Another report from the same research organisation asserted that in the social care sector, 'Opportunities to move up the pay scale are limited and training is infrequent and basic. In addition, working conditions are often poor' (Gardiner and Hussein, 2015, 5). As the social care sector offers such poor conditions and limited prospects of advancement and is therefore considered a sector characterised by precarity, it is unsurprising that it faces difficulties in attracting young employees. Furthermore, the specific needs of the sector may not be congruent with the skills and attributes of many young people.

\section{Mismatch of needs}

Our interviews demonstrated that the values and personal attributes that are required to work in the social care sector include empathy and understanding:

"the key skills needed by organisations are essentially those held by people who can 'see the person', that is who can empathise and relate to people in need" (Provider 1).

"Essentially, a caring disposition, compassion and empathy are the skills that are needed. Indeed, this is not just a job. It is a person the candidate is going to look after!" (Provider 2).

The representatives of the social care sector that we interviewed stated clearly that what they require in entry level staff are 'soft' and experience based skills and value-based attributes rather formal qualifications. This finding is mirrored in research undertaken by Skills for Care which found that one of the key attributes sought after by social care employers was 'a rapport or personality match' $(2013$, iv). These requirements contrast with the current policy emphasis on moulding the educational system to boost the qualifications levels of young people. An SVQ (Scottish Vocational Qualification) is the minimum qualification for entry level jobs, and employers are required to have 
mechanisms in place to ensure that staff can achieve this qualification if they do not already possess it.

Although previously a demanding (albeit rewarding) traditional vocational profession, providing support and care for those in need is now perceived by many as a last resort job opportunity; as one interviewee put it, the "thing to do when everything else fails" (Provider 3). The SSSC has been trying to address the view that care work is not a profession but a job only accepted by those with limited opportunities. The SSSC has proposed regulating the social care sector workforce through registration to professionalise the sector and provide reassurance to both carers and users regarding service standards. However, some interviewees considered regulation to be a potential pitfall:

"This [social care] is a heavily regulated sector and many individuals providing care at home find the cost of regulations too high to sustain. Moreover, there is a lot of responsibility involved, both in providing care to individuals and keeping up with regulations" (Provider 3).

Whether regulation is a burden that impacts upon the recruitment and retention of staff is open to debate. Despite the efforts to professionalise social care work from entry level onwards, for many, entry levels jobs are often a 'default' career choice taken when there are no other employment opportunities available. As one of our interviewees suggested:

"As it stands, the evidence suggests that among women the likely, entry level career choice is hairdressing and care, whilst among men, more manual types of jobs. What is lacking is a clear understanding of the potential career pathways available in this sector. It is important that young people are informed about this in order to make informed choices" (Representative body).

The view that social care is demanding and poorly remunerated (Gardiner and Hussein, 2015) is often attributed to the poor image of the sector, rather than a consequence of employment and labour market policies. The representatives of the sector we spoke to believed that social care is perceived as a dead-end profession and felt that something needs to be done in order to "sell the sector as a career choice" (Provider 1). This is being addressed by the SSSC, which is currently working to raise awareness of social care as a positive career choice, e.g. by highlighting the opportunities it provides to experience a range of settings and career progression. As one representative of the sector argued,

"Training opportunities exist in organisations operating in the social care sector. What is clear is the lack of understanding or knowledge of the opportunities and career options that the social care sector offers. This sector provides the opportunity 'to move across the ladder horizontally', that is, employees can move around to gain experience working for different organisations and moving up the career ladder in this way" (Representative body).

Those holding this view argued that raising awareness of the different career pathways available could improve the image of the care sector. However, the reality recounted by some care providers contrasts with such a positive portrayal:

"For these reasons it is not a sector in which people consider making a career: a) it is not an 'easy' sector for the type of tasks/work required, providing care means a variety of things, first of all it means dealing with someone who has health issues or other difficulties; $b$ ) it is 
not a well-paid job, actually we are even struggling to pay the living wage sometimes and we use, as other care organisations, zero hours contracts. Thus, workers do not have a guaranteed income every month" (Provider 4).

Moreover, raising awareness of the career pathways available in the sector offers little to assuage the doubts young people have about working in the social care sector. Indeed, although our young participants demonstrated some awareness that it could be a rewarding career, they expressed concerns about the levels of pay in the sector as well as the difficulty of the work involved:

"I think from seeing what nursing staff and community care staff do... for my gran, she's like 91 and she's got a lot of people coming in and out of her house and I just think that they do a very hard job and they don't get paid very well for it" (Shona $\left.{ }^{8}\right)$.

Given some of the concerns expressed by researchers and policymakers in Scotland regarding the precarity young people encounter in the labour market, the conditions of the social care sector which our research found is unlikely to change the negative perceptions young people currently hold: 'Insecure contracts, in particular zero-hours contracts, are prevalent among care workers, particularly in domiciliary care...while the flexibility they offer suits some workers, too often they are a burden that offers little security of work or income' (Gardiner and Hussein, 2015, 33). Moreover, even if issues such as pay and conditions were addressed by the sector, the young people in our study believed that providing care for the elderly involved certain aptitudes which could not be learned:

Shona: "It's not something I think I'm cut out for".

Fiona: "Yeah, I think you have to be cut out for it".

Andrew: "It's something that you'd have to have a caring nature...".

Maria: "Passion for...".

Andrew: "It's almost something that's genetic, something that you're built in with. I don't think everyone has the capability to be loving in that sense to a stranger".

It appears that key issues dissuade the young people we spoke to from pursuing a career in the social care sector: the perceptions that the work requires innate aptitudes, or that working with the elderly requires a vocational commitment which is inadequately rewarded with low pay and poor working conditions in the sector.

\section{Difficulties of finding a job - experience and employability}

The young people we interviewed consistently expressed concerns regarding their employability and felt that there were an increasing number of hurdles to overcome to prove to employers that they were 'job-ready'. Some felt that their age would present a barrier, but a recurring theme was the issue of gaining experience:

"a lot of jobs, they'll look for experience, but then it's like then 'well how do I get experience if you can't get into a job to get into that sector in the first place?' It's a big circle that keeps on

\footnotetext{
${ }^{8}$ Names used here are invented to protect interviewees' identity
} 
going round. How are you supposed to get anywhere? It's kind of getting your foot in the door first of all" (Maria).

Young people also believed that the labour market had become more competitive in general and that even with some experience, it was difficult to find work:

"it's just really off putting to see '280 people have applied for this job'. Oh right, well now I'm one out of 280, you know, so that just for me is really frustrating to say, yeah well I put my application in and they sent me an email, awesome. It's just frustrating to see another 300 people applied for the same job" (Natalie).

"Is there any point in me applying? I don't really... yeah I'm always thinking 'what can I do to make myself look better, to make myself look more attractive to employers?' It's kind of difficult to know what they're looking for" (Maria).

"For a lot of the graduate schemes, I did work experience last summer so that I could, like, would find it easier, hopefully, to get a job and a lot of the graduate schemes it's like online tests, you have to get through them first before they can even look at your experience, so I think that's a major barrier because the UK civil service one... I was talking to loads of people on my placement in the summer and there's people who had PhDs from like Oxford and Cambridge and it took them three times to get in" (Shona).

When discussing how to gain access to employment young people raised the prospect of volunteering to 'get their foot in the door'. However when pressed further on this, only one of the participants was actively involved in volunteering, with others citing current work commitments and studies as higher priorities. Concerns were also expressed by the young people about how to sustain themselves whilst working unpaid. Moreover, the participant who was a volunteer in a local food bank did not actually value it as a site for gaining skills that would enhance his employability:

"If you were going to look at it objectively as obviously something that sounds good and looks good on a CV and things like that but...I don't even know if that's something that employers - especially employers in any sort of business - I don't really know if a food bank's really - you know packing bags and filling out administrative bureaucratic forms for people that are coming in - I don't think is really good employability experience" (Andrew).

The young people also expressed concerns about how to get the first step into a particular sector and their strategy was revealed by the following exchange in one of our focus groups:

Shona: "I think if you take a job that's, not beneath your skill level but, you know what I mean then you might get opportunities after that".

Fiona: "It's a step in the door".

Therefore, despite being on the verge of completing a course of higher education, the young people we spoke to seemed resigned to gaining relevant employment by entering the labour market in positions which did not require the qualifications they currently held or would shortly acquire. Such views reflect analysis of the 2008 wave of the European Social Survey which suggests that young people's perceptions of their employability are negatively affected by a downturn in the labour 
market, and that this perception is shaped more by general labour market slumps than the experience of their peers (Reeskens and Van Oorschot, 2012).

\section{Reflections and conclusions}

Our research has revealed that a combination of supply and demand side factors pose considerable challenges in recruiting young participants into a career in the social care sector in Scotland. The scarcity of resources within the sector threatens both the quality of provision and employees' working conditions, all of which is evident during a transitional phase in the governance of social care in Scotland. The evidence presented in this paper suggests that further research is required to identify and address the potential contradictions of job creation strategies and in particular their potential 'precariatization' effect on young people. Although Scotland shares many similarities with its European counterparts, comparative analysis may uncover diverse challenges and potential responses. Therefore our findings offer a baseline for future projects to investigate the effectiveness of policies which are tailored to the needs of the contexts within which they are situated.

Our findings suggest that low pay and insecurity pose significant barriers to promoting the social care sector as an attractive employment pathway for young people who tend to perceive it as a sector which offers precarious employment opportunities. In addition, evidence of resource scarcity challenges the validity of the continuing emphasis placed by some UK policymakers on the skills shortages of young people. As MacDonald (2011) suggests, the supply of highly skilled workers is simply not being matched by labour market demand. What social care providers require in employees are basic educational attainments and specific skills such as empathy, a caring disposition and ultimately an interest in working with vulnerable members of society. In some sub sectors of social care the skills required by employers (such as the capacity to fulfil intimate tasks required by clients) are learned through life experience and some younger people may not be suited to this, as one of our interviewees expressed:

"We do employ people with no specific skills or education in the sector as sometimes it is life that gives a person the skills we need in our company" (Provider 5).

Indeed, the reluctance of many providers to participate in the research reflected a general preference for employing older and more mature carer staff, who were also favoured by clients, particularly in providing care to elderly people. Addressing this issue of the perceived unsuitability of younger employees in some subsectors of care requires greater attention if this sector is to be promoted as a career option for young people. Raising awareness of social care as a career option is a worthy policy objective, providing the nature of the work is fully explained, in conjunction with the softer skills needed and the value of care. This has the potential to improve the quality of care provided by attracting the right people. While there is potential for young people to begin the professional journey through apprenticeships and then later by mentoring and shadowing into the job - as proposed by the SSSC - it is also necessary to ensure this experience reflects a positive career choice on the part of applicants, rather than a last resort option. Similarly, while encouraging providers to strive for quality and a good reputation, policy expectations should be re-evaluated to reflect the reality of scarce resources.

This is particularly relevant given that underfunding can mean cost cutting, resulting in only short visits to clients by underpaid staff, as one provider explained: 
"I think that the government needs to eradicate the 15-minute visits to clients, it is not helpful for the provider and offers no real level of interaction for the client. Workers are invariably rushing in and out through no fault of their own" (Provider 5).

Above all, it is necessary to recognise the support that quality care entails. As one interviewee noted:

"what message is sent out if working with and for the elderly and those who need care is underpaid?.... It is about valuing the vulnerable" (Provider 2).

Our research has only begun to uncover some of the flaws of job creation policies that fail to appreciate the fragility of contemporary labour markets, which in the case of social care threatens to exacerbate the acuteness of employment insecurity for young workers (MacDonald, 2011). Our findings can be considered as an early warning sign for current social care workforce strategies and their impact on all workers but young workers in particular. We anticipate that future, more extensive, research concentrated on the lived experience of workers in the sector exposed to precarity and low pay could yield significant findings. In addition we recommend that research on the long-term viability of current workforce models must be prioritised if the integration of health and social care services is to benefit service users and offer sustainable employment opportunities.

Although specific to the context of our study, our analysis of employment conditions and staff recruitment challenges in the social care sector reveals some of the contradictions of the neoliberal supply side approach to employability and therefore contributes towards operationalising the theory of 'precarity' as a framework to interpret contemporary socio-economic changes linked to labour market dynamics (della Porta et al, 2015). Our discussion, has demonstrated how the supply side approach represents a key rhetorical and policy practice component of the current dynamics of precariatization of youth employment. The policies we have discussed in the paper create a young workforce that is insecure and embroiled in a qualifications 'arms race' unsuited to a sector that is less interested in academic credentials than employing staff with those very soft 'social' skills that the current labour market context actually erodes by the alienating experience of employees becoming 'entrepreneurs of the self' (Foucault, 2010). Moreover, social care providers are being asked to promote the sector with little consideration of the effects of prolonged funding constraints on the practice and image of care provision. Indeed, the longstanding Council Tax freeze in Scotland has impacted the budgets of local authorities and contributed towards the inability of social care providers to offer competitive wages and career development programmes (see Rummery and McAngus, 2015).

Still, from a theoretical perspective, we have expanded the understanding of precarity by highlighting the gap between policy rhetoric and practice in a given policy context. The Scottish Government has frequently referred to principles of solidarity to challenge the austerity policies of their Westminster opponents. However, their current position is ambivalent: on the one hand their support in February 2016 of a Living Wage for care workers ${ }^{9}$ while, on the other hand, maintaining a flagship low taxation policy which has placed funding constraints upon local authorities which have been responsible for ensuring social care provision. Although in March 2016 the Scottish

\footnotetext{
${ }^{9}$ http://news.scotland.gov.uk/News/Living-Wage-for-care-workers-222b.aspx
} 
Government announced amendments to some of aspects of the Council Tax, these proposals have fallen considerably short of the recommendations of the Report of the Commission on Local Tax Reform, jointly established by the Scottish Government and $\operatorname{COSLA}{ }^{10}$, which concluded that 'the present Council Tax system must end' $(2015,79)$. Therefore although the support for a Living Wage for carers is certainly a step in the right direction, providers such as those we interviewed have revealed they are currently struggling to pay this wage. Funding concerns are mirrored by uncertainties surrounding the new health and social care governance arrangements. These issues, among others highlighted in this paper, pose considerable challenges in terms of the capacity of the social care sector to persuade young people that a career in social care is an attractive prospect. Thus the contradictions within the Scottish Government's supposed commitment to building a skilled young workforce merits much closer scrutiny. A more evidence-based and long-term sustainable social care workforce strategy seems more important than ever.

The research contained within this paper has been made possible with the support and funding of the European Commission.

\section{References}

Age UK, 2014, Care in Crisis, London

Audit Scotland, 2015, Health and Social Care Integration, Edinburgh

Benach, J, Gimeno, D and Benavides, FG, 2002, Types of employment and health in the European Union, Luxemburg, Office of Official Publications of the European Communities

Benavides, FG and Benach, J, 1999, Precarious employment and health related outcomes in the European Union, European Foundation for the Improvement of Living and Working Conditions, Luxemburg, Office for Official Publications of the European Communities

Bridge, S, 2010, Rethinking Enterprise Policy: Can Failure Trigger New Understanding? Palgrave, Macmillan

Commission on Local Tax Reform, 2015, Just Change: A New Approach to Local Taxation

Cremin, C, 2010, 'Never employable enough: The (im) possibility of satisfying the boss's desire', Organization, 17(2), 131-149

della Porta, D, Hänninen, S, Siisiäinen, M, Silvasti, T, eds, 2015, The New Social Division: Making and Unmaking Precarity, Palgrave Macmillan

Ellis K, 2015, Personalisation, ambiguity and conflict: Matland's model of policy implementation and the'transformation'of adult social care in England. Policy \& Politics, 43(2), 239-254.

Hudson, B, and Henwood, M, 2002, The NHS and social care: the final countdown? Policy \& Politics, 30(2), 153-166.

Foucault, M, 2010, The Birth Of Biopolitics, Lectures At The College De France, 1978-1979, Palgrave Macmillan

${ }^{10}$ Convention of Scottish Local Authorities 
Furlong, A and Cartmel, F, 2004, Vulnerable young men in fragile labour markets: Employment, unemployment and the search for long-term security, York, Joseph Rowntree Foundation

Furlong, A and Kelly, P, 2005, 'The Brazilianisation of youth transitions in Australia and the UK?' Australian Journal of Social Issues, 40(2), 207-225.

Gardiner, L, 2015, The scale of minimum wage underpayment in social care, Resolution Foundation Briefing

Gardiner, L, and Hussein, S, 2015, As if we cared: the costs and benefits of a living wage for social care workers, Resolution Foundation Report

Jessop, B, 1994, 'The transition to Post-fordism and the Schumpeterian workfare state', in R Burrows, and B Loader (eds), Towards a Post-fordist Welfare State? (pp. 13-37) Routledge

Jessop, B, 2003, 'From Thatcherism to New Labour: Neo-Liberalism, Workfarism, and Labour Market Regulation', published by the Department of Sociology, Lancaster University at: http://www.lancaster.ac.uk/sociology/research/publications/papers/iessop-from-thatcherism-tonew-labour.pdf

Low Pay Commission, 2010, National minimum wage: Low Pay Commission report 2010, London, The Stationery Office

MacDonald, R, and Marsh, J, 2005, Disconnected youth?: growing up in Britain's poor neighbourhoods, Basingstoke, Palgrave Macmillan

MacDonald, R, Shildrick, T, Webster, C, and Simpson, D, 2005, 'Growing up in poor neighbourhoods: The significance of class and place in the extended transitions of "Socially excluded" young adults', Sociology, 39 (5), 873-891

MacDonald, R, 2011, 'Youth transitions, unemployment and underemployment: Plus ça change, plus c'est la même chose?', Journal of Sociology, 47(4), 427-444

Office for National Statistics, 2014, Labour Market, at: http://www.ons.gov.uk/ons/taxonomy/index.html?nscl=Labour+Market

Peck, J and Theodore, N, 2000, 'Beyond 'Employability', Cambridge Journal of Economics, 24(6), 729749

Reeskens, T, and van Oorschot, W, 2012, 'Those who are in the gutter look at the stars? Explaining perceptions of labour market opportunities among European young adults', Work, Employment and Society,26(3), 379-395

Roberts, K and Parsell, G, 1992, 'The Stratification of Youth Training', British Journal of Education and Work 5: 65-83.

Rose, N, 2000, 'Community, citizenship, and the third way', American behavioral scientist, 43(9), 1395-1411

Rummery, K, and McAngus, C, ,2015, The Future of Social Policy in Scotland: Will Further Devolved Powers Lead to Better Social Policies for Disabled People?, The Political Quarterly, 86(2), 234-239

Scottish Affairs Committee, 2014, Zero Hours Contracts in Scotland Interim Report, House of Commons, London, The Stationery Office 
Scottish Care, 2015, In the Front Line: Social Care Providers Survey Report on Recruitment and Retention, Ayr

Scottish Government, 2012, Action for Jobs - Supporting Young Scots Into Work: Scotland's Youth Employment Strategy, Edinburgh, Scottish Government

Scottish Government, 2014, Developing the Young Workforce, Scotland's Youth Employment Strategy: Implementing the Recommendations of the Commission for Developing Scotland's Young Workforce, Edinburgh, Scottish Government

Scottish Government, 2016, Quarterly Labour Market Briefing February 2016, at: http://www.gov.scot/Topics/Statistics/Browse/Labour-Market/AnalyticalPapers

Scottish Parliament Economy, Energy and Tourism Committee, 2013, Underemployment in Scotland: 6th Report, 2013, Session 4, Edinburgh, Scottish Parliament

Scottish Social Services Council, 2015, Scottish Social Services Sector: Report on 2014 Workforce Data, Official Statistics Publication for Scotland

Shildrick, TA, MacDonald, R, Webster, C, and Garthwaite, K, 2012, Poverty and insecurity: life in lowpay, no-pay Britain, Policy Press

Skills for Care, 2013, Why are some employers more successful than others in retaining their workforce?, Ekosgen

Skills for Care, 2014, National Minimum Data Set for Social Care (NMDS-SC) Trend Briefing Issue 2

Standing, G, 2011, The Precariat: The new dangerous class, Hodder Arnold 